at Work," Canadian Journal of Economics and Political Science, XVII (1951), Pp. 320-27. "On this process of professionalization see Everett C. Hughes, "Studying the Nurse's Work," American Journal of Nursing, 51 (May, 1951), pp. 294-5; and "Discussion of The Public Librarian," in A Forum on the Public Library Inquiry, ed. by Lester Asheim (New York: Columbia University Press, 1950), pp. 106-14.

"Robert E. Park, Race and Culture (Free Press: Glencoe, 1950), pp. 345-56 and 372-76.

\title{
professors of adult education meet at St. Louis
}

Professors of adult education from a number of universities held a special meeting at the AEA Annual Conference in St. Louis on Friday morning, November 11.

This meeting was a continuation of discussions begun at the University of Illinois' Allerton House in May, 1955. The Allerton meeting (reported in this journal's summer, 1955 issue) was the first time professors of adult education had come together as a group to discuss common interests and problems. Among the topics they discussed were: What should be taught in university courses in adult education? Is there a well-defined body of content in adult education? May adult education be considered a discipline? How can professors of adult education most usefully recruit, train, and place leaders for the adult education movement?

It was clear to these professors that more discussion of these problems was needed, so they made plans to get together again at the Annual Conference in St. Louis. Meanwhile the Center for the Study of Liberal Education for Adults generously arranged to write up the Allerton discussions and distribute them in advance of the
St. Louis Meeting. Jim Whipple of the Center's staff did this job. Professor Jack London of the University of California at Berkeley did most of the work in preparing the agenda and making arrangements for the Allerton meeting.

At the St. Louis meeting the professors discussed an agenda prepared by Professor Coolie Verner of Florida State University. It consisted of problems like those in the second paragraph above. It soon became apparent that lengthy discussions would be needed to work through problems of this order. Accordingly, it was decided to ask the Delegate Assembly to approve a request for funds to make further discussions possible. Many of the professors had had to pay their own way to the Allerton and St. Louis meetings, and this kept at least half of their colleagues away. Some financial assistance would do much to help all professors of adult education to meet occasionally to discuss the training of leaders of adult education, a problem of obvious importance to the entire movement.

Watson Dickerman University of Micbigan 